\title{
APLIKASI LOGIKA FUZZY DALAM MENGOPTIMALKAN PRODUKSI MINYAK KELAPA SAWIT DI PT. WARU KALTIM PLANTATION MENGGUNAKAN METODE MAMDANI
}

\author{
Akbar Rizky Wardani ${ }^{1)}$, Yuki Novia Nasution ${ }^{2)}$, Fidia Deny Tisna Amijaya ${ }^{3)}$ \\ 1), 2), 3) Program Studi Statistika FMIPA Universitas Mulawarman \\ Jl. Barong Tongkok No. 5 Kampus Unmul Gn. Kelua Sempaja Samarinda 75119 \\ E-Mail : : akbarrizky507@gmail.com ${ }^{1)}$; yuki.novia.n@gmail.com ${ }^{2)}$; fidiadta@gmail.com ${ }^{3)}$
}

\begin{abstract}
ABSTRAK
Produksi minyak kelapa sawit penting untuk diperhatikan di PT. Waru Kaltim Plantation (WKP) untuk mendapatkan hasil produksi yang optimal. Oleh karena itu perlu dikembangkan sistem yang dapat untuk memprediksi jumlah minyak kelapa sawit yang harus diproduksi. Dalam penelitian ini, logika fuzzy yang mengimplementasikan fuzzy Mamdani digunakan untuk memprediksi jumlah produksi minyak kelapa sawit berdasarkan data persediaan dan data permintaan. Berdasarkan hasil perhitungan yang telah dilakukan, dengan variabel input permintaan $2.799,918$ ton dan persediaan 1.593,21 ton pada bulan Januari 2016, metode fuzzy Mamdani mendapatkan total minyak kelapa sawit yang harus diproduksi adalah 3.085,753 ton dan metode fuzzy. Hal ini menunjukkan bahwa metode fuzzy Mamdani dapat diterapkan untuk memprediksi jumlah produksi minyak kelapa sawit di PT. Waru Kaltim Plantation (WKP). Berdasarkan hasil perhitungan dengan menggunakan ukuran keakurasian MAPE metode fuzzy Mamdani memiliki nilai MAPE 17,225\% sehingga dapat disimpulkan bahwa metode fuzzy Mamdani baik digunakan untuk memprediksi minyak kelapa sawit di PT. WKP periode tahun 2013 sampai 2015.
\end{abstract}

Kata Kunci: Metode fuzzy Mamdani, Metode fuzzy Sugeno, MAPE, Minyak Kelapa Sawit.

\section{PENDAhuluan}

Logika yang hanya berdasarkan atas dua nilai kebenaran yaitu TRUE (1) dan FALSE (0) terkadang dirasakan kurang lengkap untuk menyatakan logika berpikir manusia, sehingga dikembangkan logika yang tidak hanya bernilai 0 atau 1 tetapi menggunakan logika yang mempunyai interval nilai antara $[0,1]$ yang disebut dengan logika samar (fuzzy). Logika fuzzy diperkenalkan pada tahun 1965 oleh Lotfi A. Zadeh, seorang Professor di bidang ilmu komputer, Universitas California, Barkley. Logika fuzzy dipakai untuk menyatakan data atau informasi yang bersifat tidak pasti atau samar [1].

Saat ini, penggunaan terbesar logika samar terdapat pada bidang sistem pakar kabur (fuzzy expert system). Logika samar yang diterapkan pada sistem pakar kabur mencakup beberapa bidang, antara lain aplikasi teknik, pengenalan pola, aplikasi media dan aplikasi finansial [2].

Dari masalah mengoptimalkan produksi barang, banyak metode maupun teknik yang digunakan. Metode yang paling sering digunakan adalah logika himpunan tegas. Akan tetapi logika himpunan tegas tidak dapat dioperasikan atau digunakan oleh khalayak umum, karena selain agak rumit dalam perhitungan, kendala-kendala dalam produksi juga akan mempersulit penyelesaian masalah mengoptimalkan produksi barang. Selain logika himpunan tegas, logika fuzzy juga dapat digunakan dalam masalah mengoptimalkan produksi barang. Metode yang dapat digunakan dalam pengaplikasian logika fuzzy pada produksi barang di perusahaan antara lain adalah metode Mamdani, metode Tsukamoto, dan metode Sugeno [3].

Perbedaan dari ketiga metode logika fuzzy yang telah disebutkan adalah pada saat proses evaluasi aturan dalam mesin inferensi, metode Tsukamoto menggunakan fungsi implikasi minimum untuk mendapatkan nilai $\alpha$-predikat dari tiap-tiap rule, dalam hal ini $\alpha$-predikat merupakan nilai minimum dari hasil kedua implikasi antar variabel yang digunakan. Pada Metode Tsukamoto masing-masing $\alpha$-predikat digunakan untuk menghitung hasil inferensi secara tegas (crisp) serta hasil akhir diperoleh dengan menggunakan rata-rata terbobotnya, sedangkan metode Sugeno mirip dengan metode Mamdani, hanya output tidak berupa himpunan fuzzy, melainkan berupa konstanta atau persamaan linier [4].

Provinsi Kalimantan Timur yang terbagi dalam tujuh kabupaten dan tiga kota memiliki wilayah 208.657,74 $\mathrm{Km}^{2}$, Kabupaten Penajam Paser Utara merupakan salah satunya. Potensi pada sektor perkebunan di Kabupaten Penajam sangat menjanjikan. Secara umum produksi pertanian tanaman perkebunan di Kabupaten Penajam Paser Utara terdiri dari kelapa sawit, karet, kelapa, kopi, lada dan kakao. Komoditas kelapa sawit merupakan tanaman perkebunan utama di Penajam Paser Utara [5].

Menurut laman PT. BSI Group Indonesia PT. Waru Kaltim Plantation (WKP) merupakan anak perusahaan dari PT Astra Agro Lestari Tbk dengan 
luas area perkebunan 13.244,35 Ha. Suatu perusahaan pasti menginginkan untuk dapat memperoleh keuntungan yang maksimal. Beberapa hal yang mempengaruhi pengoptimalan keuntungan, antara lain biaya produksi, biaya transportasi, maupun teknik dalam penjualan. Untuk itu, suatu perusahaan pasti akan melakukan riset maupun analisa terhadap produk-produk yang akan ditawarkan ke pasar atau konsumen [3].

Pada perusahaan, mengoptimalkan produksi barang akan memberikan pengaruh besar, karena selain pengoptimalan bahan baku yang digunakan, hal ini juga akan berpengaruh besar pada sektor biaya atau finansial. Pengoptimalan produksi barang pada perusahaan berpengaruh pada sektor finansial karena dapat memperkirakan pembelanjaan bahan baku, selain itu juga pengoptimalan dalam hal produksi maupun biaya transportasi dan penyimpanan [3].

Hasil penelitian Salikin (2011) menunjukkan berapa banyak barang yang seharusnya diproduksi oleh perusahaan jika variabel-variabelnya berupa bilangan fuzzy dengan menggunakan perhitungan metode Mamdani dan Sugeno. Selanjutnya Lumbangaol (2013) meneliti pengenalan pasien berdasarkan kriteria yang paling mendukung menggambarkan keluhan-keluhan atau kekuatan fisik pasien sehingga pasien lebih cepat ditangani. Dalam penelitian ini akan menggunakan metode Mamdani.

Berdasarkan hal-hal yang telah diuraikan di atas, maka penulis tertarik untuk melakukan penelitian tentang "Aplikasi Logika Fuzzy Dalam Mengoptimalkan Produksi Minyak Kelapa Sawit di PT. Waru Kaltim Plantation (WKP) dengan menggunakan Metode Mamdani”.

\section{TINJAUAN PUSTAKA}

\section{A. Teori Peramalan}

Secara umum pengertian peramalan adalah tafsiran. Namun dengan menggunakan teknikteknik tertentu maka peramalan bukan hanya sekedar tafsiran. Ada beberapa definisi tentang peramalan, diantaranya:

a. Peramalan atau forecasting diartikan sebagai penggunaan teknik-teknik statistik dalam bentuk gambaran masa depan berdasarkan pengolahan angka-angka historis [8].

b. Peramalan merupakan suatu fungsi bisnis yang berusaha memperkirakan penjualan dan penggunaan produk sehingga produk dapat dibuat dalam kuantitas yang tepat [9].

c. Peramalan adalah rencana atau estimasi kejadian masa depan yang tidak pasti.

Metode peramalan merupakan cara memperkirakan apa yang akan terjadi pada masa depan secara sistematis dan pragmatis atas dasar data yang relevan pada masa yang lalu, sehingga dengan demikian metode peramalan diharapkan dapat memberikan objektivitas yang lebih besar. Selain itu, metode peramalan dapat memberikan cara pengerjaan yang teratur dan terarah, dengan demikian dapat dimungkinkan penggunaan teknik analisis yang lebih maju. Dengan penggunaan teknik-teknik tersebut maka diharapkan dapat memberikan tingkat kepercayaan dan keyakinan yang lebih besar, karena dapat diuji penyimpangan atau deviasi yang terjadi secara ilmiah [10].

\section{B. Mean Percentage Error}

Teknik peramalan tidak selamanya selalu tepat karena teknik peramalan yang digunakan belum tentu sesuai dengan sifat datanya. Oleh karena itu, perlu dilakukan evaluasi peramalan sehingga dapat diketahui sesuai atau tidaknya teknik peramalan yang digunakan, sehingga dapat dipilih dan ditentukan teknik peramalan yang lebih sesuai dengan cara menentukan batas toleransi peramalan atas penyimpangan yang terjadi.

Pada prinsipnya, evaluasi peramalan dilakukan dengan membandingkan hasil prakiraan dengan kenyataan yang terjadi. Penggunaan teknik peramalan yang menghasilkan penyimpangan terkecil adalah teknik peramalan yang paling sesuai untuk digunakan.

Besarnya error peramalan dihitung dengan mengurangi data riil dengan besarnya ramalan. Dalam menghitung error peramalan digunakan Means Absolute Percentage Error (MAPE) merupakan nilai tengah kesalahan persentase absolut dari suatu peramalan.

$$
M A P E=\frac{\sum_{i=1}^{n} \frac{\left|X_{i}-F_{i}\right|}{X_{i}} \times 100 \%}{n}
$$

Dimana :

$X_{i}=$ Permintaan Aktual pada periode-i.

$F_{i}=$ Peramalan Permintaan pada periode-i.

$n=$ Jumlah Periode peramalan yang terlibat.

Jika nilai MAPE $<25 \%$ maka hasil simulasi dapat diterima secara memuaskan, sebaliknya jika nilai MAPE > 25\% maka hasil simulasi kurang memuaskan [11].

\section{Himpunan Tegas (Crisp)}

Kita mengenal dan menggunakan konsep himpunan dalam kehidupan sehari-hari, misalnya Himpunan Mahasiswa Jurusan Matematika, Himpunan Wanita Karya, Himpunan Pengusaha Muda Indonesia (HIPMI), Himpunan Kerukunan Tani Indonesia (HKTI), Perhimpunan Bank Swasta Nasional (Perbanas), dan lain-lain. Konsep himpunan itu tidak hanya dipergunakan secara intuitif dalam kehidupan sehari-hari, tetapi telah pula dikembangkan menjadi konsep formal dewasa ini menjadi konsep yang paling mendasar dalam matematika [12].

Secara intuitif kita memahami himpunan sebagai suatu kumpulan atau koleksi objek-objek (konkret maupun abstrak) yang mempunyai kesamaan sifat tertentu. Suatu himpunan haruslah 
terdefinisi secara tegas, dalam arti bahwa untuk setiap objek selalu dapat ditentukan secara tegas apakah objek tersebut merupakan anggota himpunan itu atau tidak. Dengan perkataan lain, untuk setiap himpunan terdapat batas yang tegas antara objek-objek yang merupakan anggota dan objek-objek yang tidak merupakan anggota dari himpunan itu (Susilo, 2003).

\section{Himpunan Fuzzy}

Himpunan fuzzy memiliki dua atribut, yaitu linguistik dan numeris. Atribut linguistik adalah atribut yang digunakan untuk penamaan suatu grup yang mewakili suatu keadaan atau kondisi tertentu dengan menggunakan bahasa alami, seperti muda, parobaya, tua, sedangkan atribut numeris adalah suatu nilai yang menunjukkan ukuran dari suatu variabel [13].

Menurut Kusumadewi dan Purnomo 2010, terdapat beberapa hal yang perlu diketahui dalam memahami sistem fuzzy yaitu:

a. Variabel fuzzy

Variabel fuzzy merupakan variabel yang dibahas dalam sistem fuzzy.

b. Himpunan fuzzy

Himpunan fuzzy merupakan suatu group yang mewakili suatu kondisi atau keadaan tertentu dalam suatu variabel fuzzy.

c. Semesta Pembicaraan

Semesta pembicaraan adalah keseluruhan nilai yang diperbolehkan untuk dioperasikan dalam suatu variabel fuzzy. Semesta pembicaraan merupakan himpunan bilangan real yang senantiasa bertambah secara monoton. Nilai semesta pembicaraan dapat berupa bilangan positif maupun negatif.

d. Domain

Domain himpunan fuzzy adalah keseluruhan nilai yang diijinkan dalam semesta pembicaraan dan boleh dioperasikan dalam suatu himpunan fuzzy. Seperti halnya semesta pembicaraan, domain merupakan himpunan bilangan real yang senantiasa bertambah secara monoton. Nilai domain dapat berupa bilangan positif maupun negatif.

\section{E. Logika Fuzzy}

Logika fuzzy pertama kali diperkenalkan oleh Zadeh tahun 1965. Dasar logika fuzzy adalah teori himpunan fuzzy. Pada teori himpunan fuzzy, peranan derajat keanggotaan atau nilai keanggotan sebagai penentu keberadaan elemen dalam suatu himpunan sangatlah penting. Pada himpunan tegas (crisp), nilai keanggotaan hanya terdapat dua kemungkinan, yaitu 0 dan 1 , sedangkan pada himpunan fuzzy, nilai keanggotaan terletak pada rentang 0 sampai 1. Apabila $x$ memiliki nilai keanggotaan fuzzy $\mu_{A}[x]=0$, berarti $x$ tidak menjadi anggota himpunan $A$, demikian pula apabila $x$ memiliki nilai keanggotaan fuzzy
$\mu_{A}[x]=1$, berarti $x$ menjadi anggota penuh pada himpunan $A$ [13].

Adapun beberapa alasan mengapa digunakannya logika fuzzy adalah [14]:

1 Konsep logika fuzzy sangat sederhana sehingga mudah dipahami, kelebihanya disbanding konsep lain bukan pada kompleksitanya, tetapi pada naturalness pendekatannya dalam memecahkan masalah.

2 Fleksibel dalam artian dapat dibangun dan dikembangkan dengan mudah tanpa harus memulainya dari "nol".

3 Logika fuzzy memberikan toleransi terhadap ketidakpresisian data. Hal ini sangat cocok dengan fakta sehari-hari.

4 Pemodelan/pemetaan untuk mencari hubungan data input-output dari sembarang sistem blackbox bisa dilakukan dengan memakai sistem fuzzy.

5 Pengetahuan atau pengalaman dari pakar dapat dengan mudah dipakai untuk membangun logika fuzzy.

6 Logika fuzzy berdasar pada bahasa manusia

\section{F. Fungsi Keanggotaan}

Fungsi Keanggotaan (membership function) adalah suatu kurva yang menunjukkan pemetaan titik-titik input data ke dalam nilai keanggotaannya. Salah satu cara yang dapat digunakan untuk mendapatkan nilai keanggotaan adalah dengan melalui pendekatan fungsi. Ada beberapa fungsi yang bisa digunakan diantaranya adalah representasi linier, representasi kurva segitiga, representasi kurva trapesium, representasi kurva bentuk bahu, dan representasi kurva-S berikut penjelasanyaa:

1. Representasi linier, pemetaan input ke derajat keanggotaannya dapat digambarkan sebagai suatu garis lurus. Bentuk ini paling sederhana dan menjadi pilihan yang baik untuk mendekati suatu konsep yang kurang jelas. Ada dua keadaan himpunan fuzzy yang linier Naik dan Turun.

2. Representasi kurva segitiga, pada dasarnya adalah gabungan antara dua representasi linier (representasi linier naik dan representasi linier turun).

3. Representasi kurva trapesium pada dasarnya seperti bentuk kurva segitiga, hanya saja ada beberapa titik yang memiliki nilai keanggotaan 1 (satu).

4. Representasi kurva bahu, daerah yang terletak di tengah-tengah suatu variabel yang dipresentasikan dalam bentuk segitiga, pada sisi kanan dan kirinya akan naik dan turun.

5. Representasi kurav-S, kurva Pertumbuhan dan Penyusutan merupakan kurva-S atau sigmoid yang berhubungan dengan kenaikan dan penurunan permukaan secara tak linier. Kurva-S untuk Pertumbuhan akan bergerak dari sisi paling kiri dengan derajat (nilai keanggotaan = 
0) ke sisi paling kanan dengan (nilai keanggotaan $=1$ ).

\section{G. Operator Fuzzy}

Seperti halnya himpunan tegas (crisp set), ada beberapa operasi yang didefinisikan secara khusus untuk mengkombinasi dan memodifikasi himpunan fuzzy. Nilai keanggotaan sebagai hasil dari operasi dua himpunan sering dikenal dengan nama fire strength atau $\alpha$-cut. Terdapat tiga operator dasar yang diciptakan oleh Zadeh, yaitu: AND, OR, dan NOT. Terdapat juga operator-operator alternatif yang dikembangkan menggunakan konsep transformasi tertentu adapun penjelasannya sebagai berikut:

1. Operator AND

Operator ini berhubungan dengan operasi interaksi pada himpunan $\alpha$-predikat sebagai hasil operasi dengan operator AND diperoleh dengan mengambil nilai keanggotaan terkecil antar elemen pada himpunan-himpunan yang bersangkutan (Cox, 1994).

$$
\mu_{A \cap B}=\min \left(\mu_{A}(x), \mu_{B}(\gamma)\right)
$$

\section{Operator OR}

Operator ini berhubungan dengan operasi union pada himpunan. $\alpha$-predikat sebagai hasil operasi dengan operator OR diperoleh dengan mengambil nilai keanggotaan terbesar antar elemen pada himpunan-himpunan yang bersangkutan (Cox, 1994).

$$
\mu_{A \cup B}=\max \left(\mu_{A}(x), \mu_{B}(\gamma)\right)
$$

\section{Operator NOT}

Operator ini berhubungan dengan operasi komplemen pada himpunan. $\alpha$-predikat sebagai hasil operasi dengan operator NOT diperoleh dengan mengurangkan nilai keanggotaan elemen pada himpunan yang bersangkutan dari 1 (Cox, 1994).

$$
\mu_{A^{\prime \prime}}=1-\mu_{A}(x)
$$

\section{H. Metode Mamdani}

Sistem inferensi fuzzy Metode Mamdani dikenal juga dengan nama metode

Max-Min. Metode Mamdani bekerja berdasarkan aturan-aturan linguistik. Metode ini diperkenalkan oleh Ebrahim H. Mamdani pada tahun 1975. Untuk mendapatkan output (hasil), diperlukan 4 tahapan [3]:

1. Pembentukan himpunan fuzzy

Pada tahapan ini, ditentukan semua variabel yang terkait dalam proses yang akan ditentukan. Untuk masing-masing variabel input, ditentukan suatu fungsi fuzzifikasi yang sesuai. Pada metode Mamdani, baik variabel input maupun variabel output dibagi menjadi satu atau lebih himpunan fuzzy.
2. Aplikasi fungsi implikasi

Pada tahapan ini, disusun basis aturan, yaitu aturan-aturan berupa implikasi-implikasi fuzzy yang menyatakan relasi antara variabel input dengan variabel output. Pada Metode Mamdani, fungsi implikasi yang digunakan adalah Min. Bentuk umumnya adalah sebagai berikut:

Jika $a$ adalah $A_{i}$ dan $b$ adalah $B_{i}$, maka $c$ adalah $C_{i}$

dengan $A_{i}, B_{i}$, dan $C_{i}$ adalah predikat-predikat fuzzy yang merupakan nilai linguistik dari masingmasing variabel. Banyaknya aturan ditentukan oleh banyaknya nilai linguistik untuk masing-masing variabel masukan.

3. Komposisi aturan

Apabila sistem terdiri dari beberapa aturan, maka inferensi diperoleh dari kumpulan dan korelasi antar aturan. Ada 3 metode yang digunakan dalam melakukan inferensi sistem fuzzy, yaitu:

a. Metode Max (Maximum)

Pada metode ini, solusi himpunan fuzzy diperoleh dengan cara mengambil nilai maksimum aturan, kemudian menggunakan nilai tersebut untuk memodifikasi daerah fuzzy dan mengaplikasikannya ke output dengan menggunakan operator OR (gabungan). Jika semua proporsi telah dievaluasi, maka output akan berisi suatu himpunan fuzzy yang merefleksikan kontribusi dari tiap-tiap proporsi. Secara umum dapat dituliskan:

$$
\mu\left(x_{i}\right)=\max \left(\mu_{s f}\left(x_{i}\right), \mu_{k f}\left(x_{i}\right)\right)
$$

dengan,

$\mu_{s f}\left(x_{i}\right)=$ nilai keanggotaan solusi fuzzy sampai aturan ke- $i$

$\mu_{k f}\left(x_{i}\right)=$ nilai keanggotaan konsekuen fuzzy aturan ke- $i$

b. Metode Additive (Sum)

Pada metode ini, solusi himpunan fuzzy diperoleh dengan cara melakukan penjumlahan terhadap semua output daerah fuzzy.

c. Metode Probabilistik (probar)

Pada metode ini, solusi himpunan fuzzy diperoleh dengan cara melakukan perkalian terhadap semua output daerah fuzzy.

\section{Defuzzifikasi}

Input dari proses penegasan adalah suatu himpunan fuzzy yang diperoleh dari komposisi aturan-aturan fuzzy, sedangkan output yang dihasilkan merupakan suatu bilangan real yang tegas. Dengan demikian jika diberikan suatu himpunan fuzzy dalam range tertentu, maka harus dapat diambil suatu nilai tegas tertentu sebagai output. 
Ada beberapa cara metode penegasan yang biasa dipakai pada komposisi aturan Mamdani yang dapat digunakan. Pada metode ini, solusi tegas diperoleh dengan cara mengambil titik pusat daerah fuzzy. Secara umum untuk domain diskrit, titik pusat adalah:

$$
Z=\frac{\sum_{i=1}^{n} d_{i} \mu_{\tilde{A}_{i}}\left(d_{i}\right)}{\sum_{i=1}^{n} \mu_{\tilde{A}_{i}}\left(d_{i}\right)}
$$

Dengan $d_{i}$ adalah nilai keluaran pada aturan ke- $i$ dan adalah derajat keanggotaan nilai keluaran pada aturan ke- $i$ sedangkan $n$ adalah banyaknya aturan yang digunakan. Untuk domain kontinu, titik pusat adalah:

$$
Z_{0}=\frac{\int_{a}^{b} z \cdot \mu_{(z)} d z}{\int_{a}^{b} \mu_{(z)} d z}
$$

Dengan $Z_{0}$ adalah nilai hasil defuzzifikasi dan $\mu_{(z)}$ adalah derajat keanggotaan titik tersebut, sedangkan $z$ adalah nilai domain ke-i.

\section{HASIL DAN PEMBAHASAN}

\section{A. Analisis Statistika Deskriptif}

Hasil perhitungan statistika deskriptif data persediaan, permintaan dan produksi minyak kelapa sawit di perusahaan WKP dengan menggunakan software SPSS 20 dapat dilihat pada Tabel 1.

Tabel 1. Statistika Deskriptif data Permintaan, Persediaan dan Produksi Minyak Kelapa Sawit PT.

WKP

\begin{tabular}{|c|c|c|c|}
\hline & Permintaan & Persediaan & Produksi \\
\hline Median & $3.685,1755$ & 972,3940 & $3.811,9070$ \\
\hline $\begin{array}{c}\text { Std. } \\
\text { Deviasi }\end{array}$ & $1.432,76475$ & 651,52075 & $1.232,88771$ \\
\hline Variansi & $2.052 .814,821$ & $424.479,292$ & $1.520 .012,101$ \\
\hline Minimum & $1.600,88$ & 368,07 & $1.816,98$ \\
\hline Mean & $3.749,7548$ & $1.121,524$ & $3.733,0707$ \\
\hline
\end{tabular}

Berdasarkan data pada Tabel 4.2 dapat dilihat terdapat beberapa ukuran pemusatan yaitu median, standar deviasi, variansi, nilai minimum, nilai maksimum dan mean (rata-rata) data minyak kelapa sawit berikut adalah penjelasannya:

1. Rata-rata permintaan minyak kelapa sawit adalah sebanyak $3.749,7548$ ton, rata-rata persediaan minyak kelapa sawit adalah sebanyak 1.121,524 ton dan jumlah rata-rata produksi minyak kelapa sawit adalah sebanyak 3.733,0707 ton.

2. Nilai median dari permintaan minyak kelapa sawit adalah sebanyak 3.685,1755 ton, median persediaan minyak kelapa sawit adalah sebanyak 972,3940 ton dan median produksi minyak kelapa sawit adalah sebanyak 3.811,9070 ton.

3. Permintaan maksimum minyak kelapa sawit sebesar 6.825,61 ton diperoleh pada bulan
April tahun 2014, persediaan maksimum minyak kelapa sawit 3.126,99 ton diperoleh pada bulan Januari tahun 2013 dan produksi maksimum minyak kelapa sawit sebesar 6.454,4 ton diperoleh pada bulan April tahun 2014.

4. Nilai permintaan minimum minyak kelapa sawit sebesar 1.600,88 ton diperoleh pada bulan Juni tahun 2015, persediaan minimum minyak kelapa sawit 368,07 ton diperoleh pada bulan Agustus tahun 2015 dan produksi minimum minyak kelapa sawit sebesar 1.816,98 ton diperoleh pada bulan Februari tahun 2015 .

\section{B. Nilai Variabel Input dan Output}

Nilai variabel input dan output merupakan nilai yang digunakan untuk membuat fungsi keanggotaan fuzzy variabel permintaan, persediaan dan produksi. Nilai variabel input dan output ditentukan oleh peneliti berdasarkan nilai maksimum, minimum dan median data minyak kelapa sawit, adapun nilai input dan output yang digunakan dalam penelitian ini adalah sebagai berikut:

Tabel 2. Nilai Variabel Input (dalam satuan ton)

\begin{tabular}{|l|c|}
\hline \multicolumn{2}{|c|}{ Variabel } \\
\hline \multicolumn{1}{|c|}{ Linguistik } & Numerik \\
\hline Permintaan Rendah & 1.601 \\
\hline Permintaan Sedang & 3.685 \\
\hline Permintaan Tinggi & 6.826 \\
\hline Persediaan Rendah & 368 \\
\hline Persediaan Sedang & 972 \\
\hline Persediaan Tinggi & 3.127 \\
\hline
\end{tabular}

Tabel 3. Nilai Variabel Output (dalam satuan ton)

\begin{tabular}{|l|c|}
\hline \multicolumn{2}{|c|}{ Variabel } \\
\hline \multicolumn{1}{|c|}{ Linguistik } & Numerik \\
\hline Produksi Rendah & 1.817 \\
\hline Produksi Sedang & 3.811 \\
\hline Produksi Tinggi & 6.454 \\
\hline
\end{tabular}

\section{Pendefinisian Aturan dan Variabel Fuzzy}

Pendefinisan aturan dan variabel fuzzy dilakukan berdasarkan diskusi pakar dengan pihak perusahaan. Diperoleh aturan fuzzy yang akan digunakan dapat dilihat pada Tabel 4.

Tabel 4. Aturan-aturan fuzzy

\begin{tabular}{|c|c|c|c|}
\hline Aturan ke- & Permintaan & Persediaan & Produksi \\
\hline 1 & Rendah & Tinggi & Rendah \\
\hline 2 & Rendah & Sedang & Rendah \\
\hline 3 & Rendah & Rendah & Rendah \\
\hline 4 & Sedang & Tinggi & Rendah \\
\hline 5 & Sedang & Sedang & Sedang \\
\hline 6 & Sedang & Rendah & Tinggi \\
\hline 7 & Tinggi & Tinggi & Tinggi \\
\hline 8 & Tinggi & Sedang & Tinggi \\
\hline 9 & Tinggi & Rendah & Tinggi \\
\hline
\end{tabular}


Susunan aturan fuzzy dipengaruhi oleh banyaknya variabel input dan variabel output. Dari dua variabel input dan output, susunan aturan yang digunakan dalam penelitian ini adalah If Permintaan (...) And Persediaan (...) Then Produksi (...).

\section{Pembentukan Himpunan Fuzzy}

Pembentukan himpunan Fuzzy atau yang sering disebut dengan tahap melakukan fuzzifikasi yaitu mengambil nilai-nilai variabel input dan menentukan derajat keanggotaannya dalam semua fuzzy set menggunakan fungsi keanggotaan masingmasing.

a. Fungsi Keanggotaan Variabel Permintaan

Fungsi keanggotaan variabel fuzzy dibuat berdasarkan nilai variabel permintaan yang terdapat pada Tabel 2. Fungsi keanggotaan permintaan yang terbentuk terdapat dalam Gambar 1.

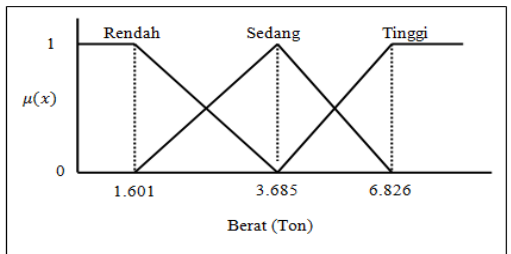

Gambar 1. Fungsi keanggotaan permintaan

fungsi keanggotaan permintaan sebagai berikut:

$$
\begin{aligned}
& \mu_{\text {Permintaan Rendah }}(x)=\left\{\begin{array}{cc}
0 ; & x \geq 3.685 \\
\frac{3.685-x}{3.685-1.601} ; & 1.601 \leq x \leq 3.685 \\
1 ; & x \leq 1.601
\end{array}\right. \\
& \mu_{\text {Permintaan Sedang }}(x)=\left\{\begin{array}{cc}
0 ; & x \leq 1.601 \vee x \geq 6.826 \\
\frac{x-1.601}{3.685-1.601} ; & 1.601 \leq x \leq 3.685 \\
\frac{6.826-x}{6.826-3.685} ; & 3.685 \leq x \leq 6.826
\end{array}\right. \\
& \mu_{\text {Permintaan Tinggi }}(x)=\left\{\begin{array}{cc}
\frac{x-3.685}{0.826-3.685} ; & 3.685 \\
1 ; & x \leq 3 \leq 68.6826
\end{array}\right.
\end{aligned}
$$

b. Fungsi Keanggotaan Persediaan

Fungsi keanggotaan variabel fuzzy dibuat berdasarkan nilai variabel persediaan yang terdapat pada Tabel 2. Fungsi keanggotaan persediaan yang terbentuk terdapat dalam Gambar 2.

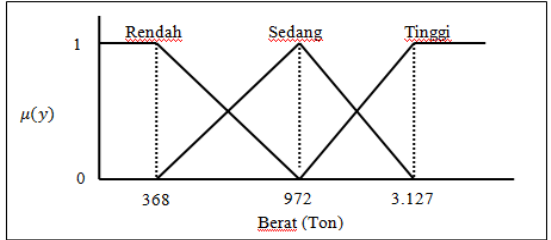

Gambar 2 .Fungsi keanggotaan persediaan fungsi keanggotaan persediaan sebagai berikut:

$$
\begin{aligned}
& \mu_{\text {Persediaan Rendah }(y)}=\left\{\begin{array}{cc}
0 ; & y \geq 972 \\
\frac{972-y}{972-368} ; & 368 \leq y \leq 972 \\
1 ; & y \leq 368
\end{array}\right. \\
& \mu_{\text {Persediaan Sedang }}(y)=\left\{\begin{array}{cc}
0 ; & y \leq 368 \vee y \geq 3.127 \\
\frac{y-368}{972-368} ; & 368 \leq y \leq 972 \\
\frac{3.127-y}{3.127-972} ; & 972 \leq y \leq 3.127 \\
1 ; & y=972
\end{array}\right. \\
& \mu_{\text {Persediaan Tinggi }}(y)=\left\{\begin{array}{cc}
0 ; & y \leq 972 \\
\frac{y-972}{3.127-972} ; & 972 \leq y \leq 3.127 \\
1 ; & y \geq 3.127
\end{array}\right.
\end{aligned}
$$

c. Fungsi Keanggotaan Produksi

Fungsi keanggotaan variabel fuzzy dibuat berdasarkan nilai variabel produksi yang terdapat pada Tabel 3. Fungsi keanggotaan produksi yang terbentuk terdapat dalam Gambar 3.

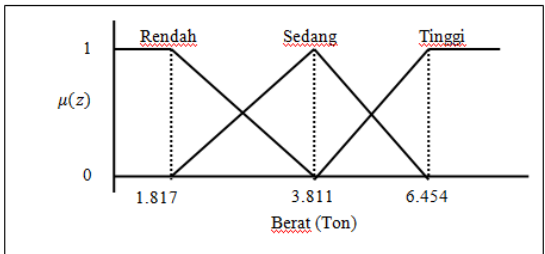

Gambar 3. Fungsi keanggotaan produksi

fungsi keanggotaan produksi sebagai berikut:

$$
\begin{aligned}
& \mu_{\text {Produks iRendah }}(z)=\left\{\begin{array}{cc}
0 ; & z \geq 3.811 \\
\frac{3.811-z}{3.811-1.817} ; & 1.817 \leq z \leq 3.811 \\
1 ; & z \leq 1.817
\end{array}\right. \\
& \mu_{\text {ProduksiSedang }}(z)=\left\{\begin{array}{cc}
0 ; & z \leq 1.817 \vee z \geq 6.454 \\
\frac{z-1.817}{3.811-1.817} ; & 1.817 \leq z \leq 3.811 \\
\frac{6.454-z}{6.454-3.811} ; & 3.811 \leq z \leq 6.454 \\
1 ; & z=3.811
\end{array}\right. \\
& \mu_{\operatorname{Pr} \text { oduksiTinggi }}(z)=\left\{\begin{array}{cc}
0 ; & z \leq 3.811 \\
\frac{z-3.811}{6.454-3.811} ; & 3.811 \leq z \leq 6.454 \\
1 ; & z \geq 6.454
\end{array}\right.
\end{aligned}
$$

\section{E. Perhitungan Manual Sistem Inferensi Fuzzy Metode Mamdani}

Pada Subbab ini akan dijelaskan proses perhitungan manual sistem inferensi fuzzy metode Mamdani berdasarkan data PT WKP, diperoleh bahwa untuk bulan Januari 2016 nilai permintaan sebanyak 2.799,918 ton dan jumlah persediaan pada bulan Desember 2015 sebanyak 1.593,21 ton, selanjutnya akan diprediksi jumlah produksi berdasarkan kedua nilai variabel tersebut. Adapun tahap perhitungan manual metode Mamdani sebagai berikut:

a. Pembentukan Himpunan Fuzzy

Pada tahap ini akan dibuat fungsi keanggotaan ketika nilai permintaan sebanyak 
2799,918 ton dan jumlah persediaan sebanyak 1593,21 ton.

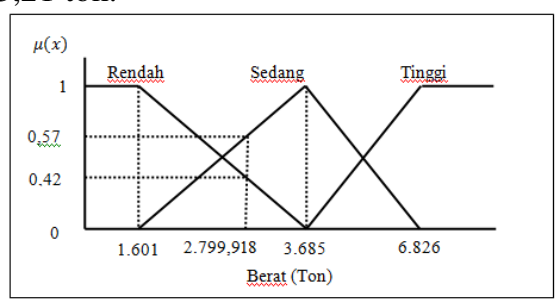

Gambar 4 Fungsi keanggotaan permintaan

Dari Gambar 4 dapat dilihat bahwa nilai permintaan sebanyak 2.799,918 menyentuh kurva rendah dan sedang sehingga dengan menggunakan Persamaan 4.1 diperoleh sebagai berikut:

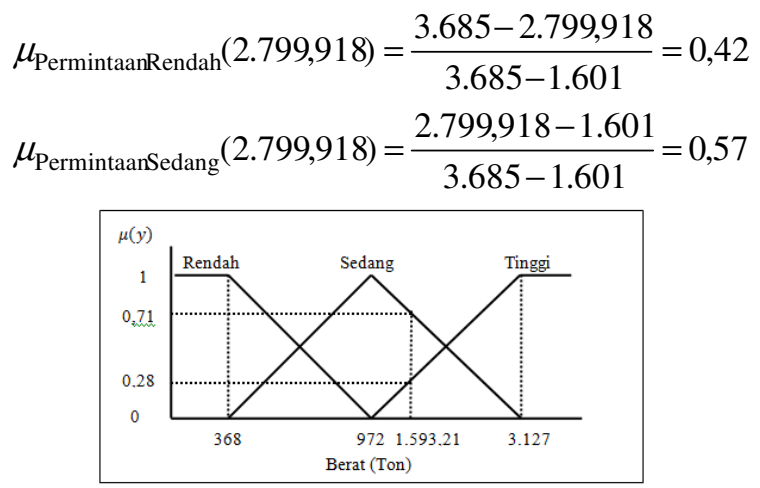

Gambar 5. Fungsi keanggotaan persediaan

Dari Gambar 5 dapat dilihat bahwa nilai persediaan sebanyak 1.593,21 menyentuh kurva sedang dan tinggi sehingga dengan menggunakan Persamaan 4.2 diperoleh sebagai berikut:

$$
\begin{aligned}
& \mu_{\text {Persediaan Sedang }}(1.593,21)=\frac{3.127-1.593,21}{3.127-972}=0,71 \\
& \mu_{\text {Persediaan Tinggi }}(1.593,21)=\frac{1.593,21-972}{3.127-972}=0,28
\end{aligned}
$$

b. Penyusunan Basis Aturan dan Fungsi Implikasi

Penyusunan basis aturan merupakan tahap penyusunan aturan-aturan yang berupa implikasi-implikasi fuzzy yang menyatakan relasi antara variabel input dan variabel output. Proses penyusunan basis aturan berdasarkan pada kombinasi dari hasil pembentukan himpunan fuzzy dan daftar aturan yang digunakan oleh perusahaan.

Fungsi implikasi yang digunakan pada metode Mamdani adalah nilai minimum di antara kedua implikasi yang ada. Nilai minimum dari hasil kedua implikasi yang ada biasanya dianamakan dengan $\alpha$-predikat. Berikut adalah penyusunan basis aturan ketika permintaan sebanyak 2.799,918 ton dan persediaan sebanyak 1.593,21 ton:

1. Aturan ke-1 [R1]
[R1] IF Permintaan Rendah AND

Persediaan Tinggi THEN Produksi Rendah.

$$
\begin{aligned}
\alpha \text {-predikat }_{1} & =\min \left(\mu_{\text {Permintaan Rendah }}\right. \\
(2.799,918) \cap & \left.\mu_{\text {Persediaan Tinggi }}(1.593,21)\right) \\
& =\min (0,42 ; 0,28)=0,28
\end{aligned}
$$

2. Aturan ke-2 [R2]

[R2] IF Permintaan Rendah AND

Persediaan Sedang THEN Produksi Rendah.

$\alpha$-predikat $_{2}=\min \left(\mu_{\text {Permintaan Rendah }}\right.$

$$
\begin{array}{r}
\left.(2.799,918) \cap \mu_{\text {PersediaanSedang }}(1.593,21)\right) \\
=\min (0,42 ; 0,71)=0,42
\end{array}
$$

3. Aturan ke-3 [R4]

[R4] IF Permintaan Sedang AND

Persediaan Tinggi THEN Produksi

Rendah.

$\alpha$-predikat $_{4}=\min \left(\mu_{\text {Permintaan Sedang }}\right.$

$$
\begin{array}{r}
\left.(2.799,918) \cap \mu_{\text {Persediaan Tinggi }}(1.593,21)\right) \\
=\min (0,57 ; 0,28)=0,28
\end{array}
$$

4. Aturan ke-4 [R5]

[R5] IF Permintaan Sedang AND

Persediaan Sedang THEN Produksi

Sedang.

$\alpha$ - predikat $_{5}=\min \left(\mu_{\text {Permintaan Sedang }}\right.$

$$
\begin{array}{r}
\left.(2.799,918) \cap \mu_{\text {PersediaanSedang }}(1.593,21)\right) \\
=\min (0,57 ; 0,71)=0,57
\end{array}
$$

c. Komposisi Aturan

Komposisi aturan digunakan untuk menentukan korelasi antara aturan didapatkan melalui pengetahuan dari sekumpulan If Then Rule (Inferensi). Metode yang digunakan dalam komposisi aturan pada penelitian ini adalah metode maksimum. Proses komposisi aturan dengan menggunakan metode maksimum dapat dijelaskan melalui Gambar 6 sampai Gambar 10 :

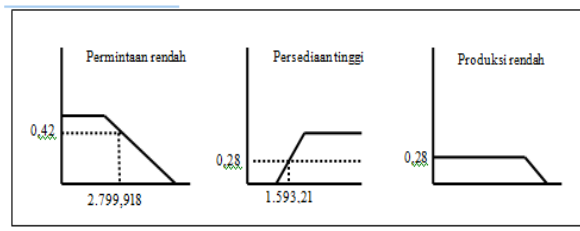

Gambar 6. Daerah hasil variabel produksi berdasarkan $\alpha$-predikat [R1]

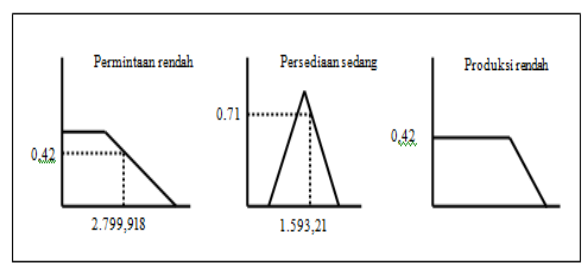

Gambar 7. Daerah hasil variabel produksi berdasarkan $\alpha$-predikat [R2] 


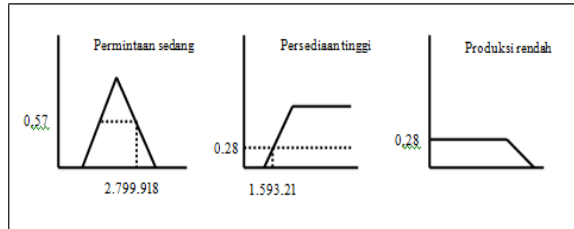

Gambar 8. Daerah hasil variabel produksi berdasarkan $\alpha$-predikat [R4]

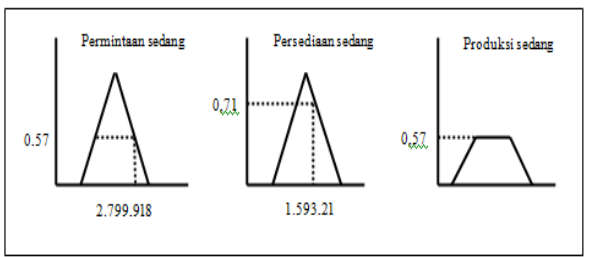

Gambar 9. Daerah hasil variabel produksi berdasarkan $\alpha$-predikat [R5]

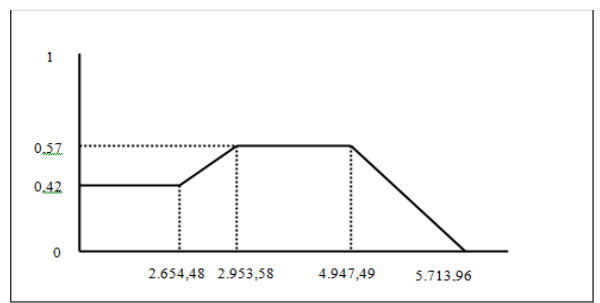

Gambar 10. Daerah hasil produksi dari [R1], [R2], [R4] dan [R5]

Berdasarkan Gambar $10 \quad$ setelah menggabungkan keempat $a$-predikat, langkah selanjutnya adalah membagi gabungan $a$ predikat tersebut ke dalam empat partisi yaitu $\mathrm{d}_{1}, \mathrm{~d}_{2}, \mathrm{~d}_{3}$ dan $\mathrm{d}_{4}$. Partisi-partisi yang telah didapat akan digunakan untuk proses defuzzifikasi perhitungan partisi menggunakan Persamaan (4.3) adalah sebagai berikut:

a. Partisi satu $\left(\mathrm{d}_{1}\right)$

$$
\begin{aligned}
& \frac{d_{1}-1.817}{3.811-1.817}=0,42 \\
& \frac{d_{1}-1.817}{1.994}=0,42 \\
& d_{1}=1.817+837,48=2.654,48
\end{aligned}
$$

b. Partisi dua $\left(\mathrm{d}_{2}\right)$

$$
\begin{aligned}
& \frac{d_{2}-1.817}{3.811-1.817}=0,57 \\
& \frac{d_{2}-1.817}{1.994}=0,57 \\
& d_{2}=1.817+1.136 .58=2.953,58
\end{aligned}
$$

c. Partisi tiga $\left(\mathrm{d}_{3}\right)$

$$
\begin{aligned}
& \frac{6.545-d_{3}}{6.545-3.811}=0,57 \\
& \frac{6.545-d_{3}}{2.643}=0,57
\end{aligned}
$$

$$
d_{3}=6.545-1506,51=4947,49
$$

Gambar 10 merupakan solusi himpunan fuzzy yang diperoleh dengan cara mengambil nilai maksimum daerah hasil produksi dari masing-masing aturan dan menggabungkannya. Kemudian menentukan fungsi keanggotaan dari Gambar 10. Fungsi keanggotaan daerah hasil produksi yang telah digabung adalah sebagai berikut:

$\mu_{\operatorname{Pr} \text { oduksi }}(z)=\left\{\begin{array}{cc}0,42 ; & z \leq 2.654,48 \\ \frac{z-1.817}{3.811-1.817} ; & 2.654,48 \leq z \leq 2.953,58 \\ 0,57 ; ; & 2.953,58 \leq z \leq 4.947,49 \\ \frac{6.545-z}{6.545-3.811} ; & 4.947,49 \leq z \leq 6.454\end{array}\right.$

d. Defuzzifikasi

Proses defuzzifikasi pada metode Mamdani menggunakan Persamaan (2.11). hasil perhitungan proses defuzzifikasi untuk variabel permintaan sebanyak 2.799,918 dan variabel persediaan sebanyak 1.593,21 adalah sebagai berikut: Defuzzifikasi yang digunakan adalah metode centroid dengan menggunakan Persamaan (2.13).

$$
\begin{aligned}
& 2.654,48 \\
& M_{1}=\int \mu(z) z d z \\
& 2.654,48 \\
& =\int(0,42) z d z=1.479 .715,455 \\
& 0 \\
& 2.953,58 \\
& M_{2}=\int \mu(z) z d z \\
& 2.654,48 \\
& =\int_{2.654,48}^{2.953,58}\left(\frac{z-1.817}{1.994}\right) z d z \\
& =0,00016 z^{3}-0,\left.445 z^{2}\right|_{2.654,48} ^{2.953,58} \\
& =418.468,546 \\
& 4.947,49 \\
& M_{3}=\int \mu(z) z d z \\
& 2.953,58 \\
& 4.947,49 \\
& =\int(0,57) z d z=4.489 .896,408 \\
& 2.953,58 \\
& M_{4}=\int_{4.947}^{6.454} \mu(z) z d z \\
& \text { 4.947,49 } \\
& =\int_{4.947,49}^{6.454}\left(\frac{6.545-z}{2.643}\right) z d z \\
& =1,22 z^{2}-0,\left.000126 z^{3}\right|_{4.947,49} ^{6.454} \\
& =2.340 .959,42 \\
& 2654,48 \quad 2654,48 \\
& A_{1}=\int_{0}^{26} \mu(z) d z=\int_{0}^{26,42}
\end{aligned}
$$




$$
\begin{aligned}
& =0,\left.42 x\right|_{0} ^{2.654,48}=1.114,882 \\
& A_{2}=\int_{2.654,48}^{2.953,58} \mu(z) d z=\int_{2.654,48}^{2.953,58}\left(\frac{z-1.817}{1.994}\right) d z \\
& =\int_{2.654,48}^{2.953,58}(0,000502 z-0,91) \\
& =0,000502 z^{2}-0,\left.91 z\right|_{2.654,48} ^{2.953,58}=148,054 \\
& A_{3}=\int_{2.953,58}^{4.947,49} \mu(z) d z=\int_{2.953,58}^{4.947,49} 0,57 \\
& =0,\left.57 z\right|_{2.953,58} ^{4.947,49}=1.136,528 \\
& A_{4}=\int_{4.947,49}^{6.454} \mu(z) d z=\int_{4.947,49}^{6.454}\left(\frac{6.454-z}{2.643}\right) d z=429,355 \\
& 2.953,58 \\
& =\int(2,44-0,000378 z) \\
& 2.654,48 \\
& =2,44 z-0,\left.000378 z^{2}\right|_{4.947,49} ^{6.454}=148,054 \\
& \begin{aligned}
Z^{*} & =\frac{\int \mu(z) z d z}{\int \mu(z) d z}=\frac{M_{1}+M_{2}+M_{3}+M_{4}}{A_{1}+A_{2}+A_{3}+A_{4}}=\frac{8.729 .039,83}{2.828,82} \\
& =3.085,753
\end{aligned}
\end{aligned}
$$

Hasil perhitungan proses defuzzifikasi dengan nilai variabel permintaan berjumlah 2.799,918 ton dan variabel persediaan berjumlah $1.593,21$ ton maka minyak kelapa sawit yang harus diproduksi adalah sebanyak 3.085,753 ton.

\section{A. Perhitungan Menggunakan Software Matlab Sistem Inferensi Fuzzy Metode Mamdani}

1. Membuat Membership Function Editor

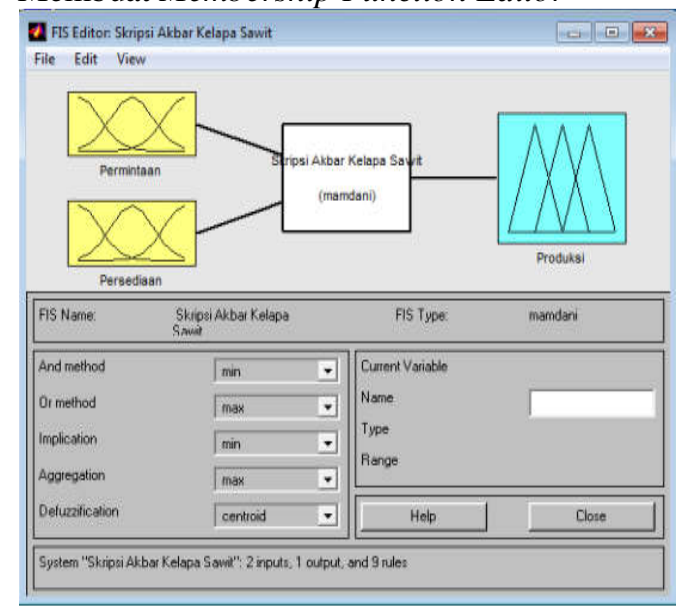

Gambar 11. Tampilan awal Membership Function

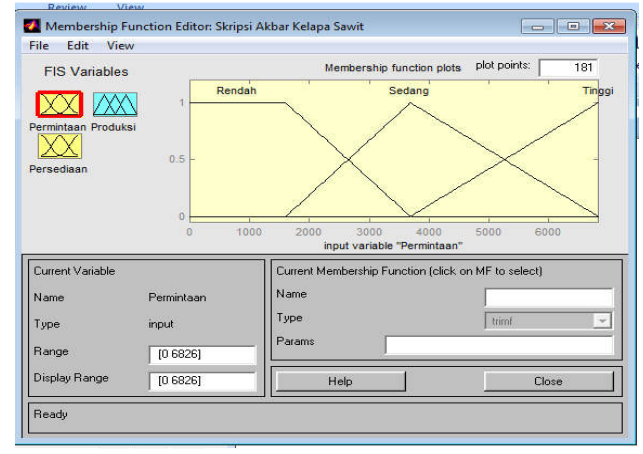

Gambar 12. Membership Function Permintaan

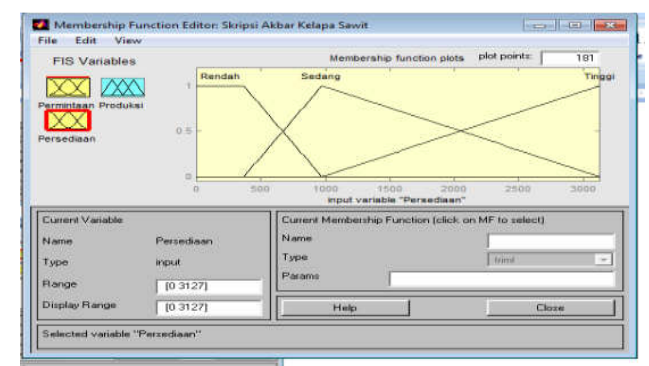

Gambar 13. Membership Function Persediaan

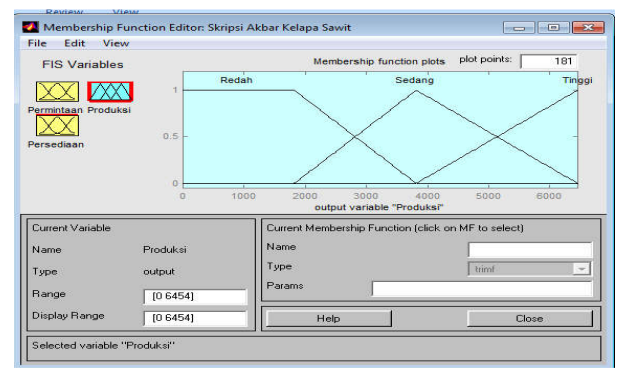

Gambar 14. Membership Function Produksi

Dari Gambar 11, 12, 13 dan 14 di atas fungsi-fungsi keanggotaan variabel masukan dan keluaran didefinisikan melalui Membership Function Editor.

Pada Gambar 12 adalah pendefinisan variabel permintaan, Gambar 13 adalah pendefinisian variabel persediaan dan Gambar 14 adalah pendefinisian variaebl produksi.

2. Membuat Rule Editor

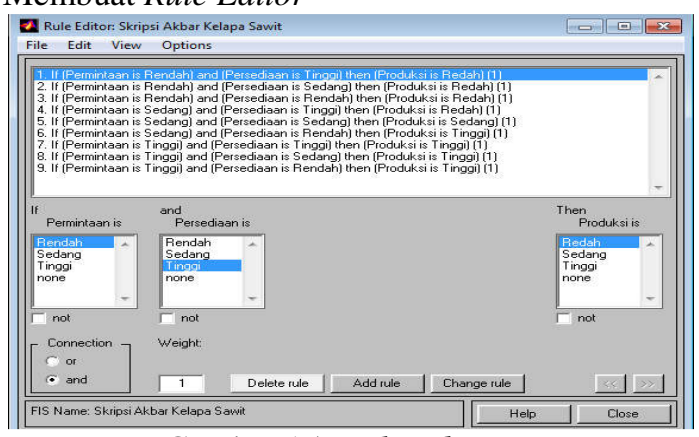

Gambar 15. Rule Editor

Pada rule editor adalah tahap dimana mendefinsikan IF-THEN rule yang digunakan yaitu sebanyak 9 aturan yang dipakai sesuai pada Gambar 15. 
3. Rule Viewer

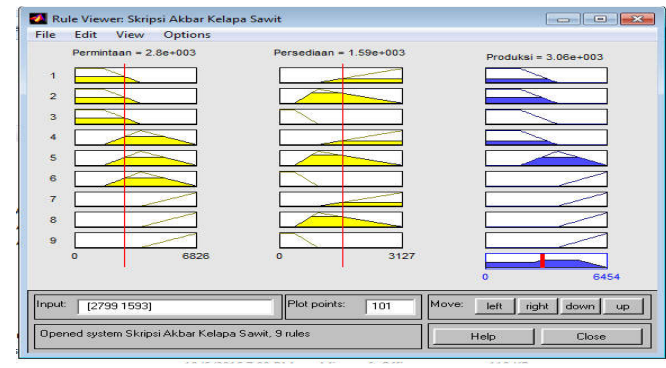

Gambar 16. Rule Viewer

Rule Viewer yang ditampilkan pada Gambar 16 adalah proses keseluruhan yang terjadi dalam metode Mamdani.

4. Surface Viewer

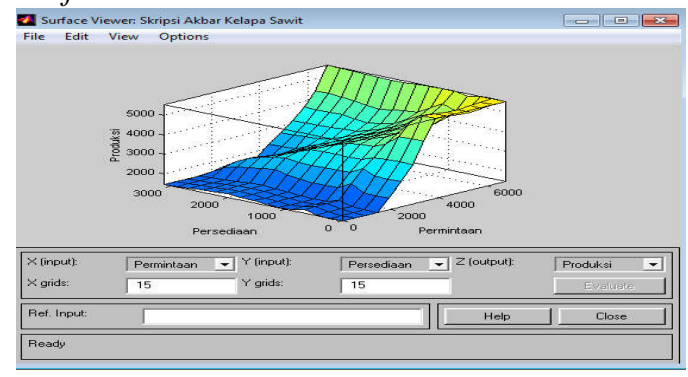

Gambar 17. Surface Viewer

Suface viewer yang ditampilakn pada Gambar 17 untuk melihat plot keseluruhan dari Metode Mamdani.

\section{B. Hasil MAPE Prediksi Metode Mamdani}

Setelah dilakukan perhitungan manual seperti yang dilakukan sebelumnya untuk mengetahui keakuratan prediksi yang dilakukan maka akan diukur dengan menggunakan MAPE, perhitungannya dengan menggunakan Persamaan 1 diperoleh,

$$
M A P E=\frac{\sum \frac{\left|X_{i}-F_{i}\right|}{X_{i}} \times 100 \%}{n}=\frac{6,02901}{35} \times 100=17,225 \%
$$

\section{KESIMPULAN}

Berdasarkan hasil uraian yang telah dikemukakan sebelumnya, hasil analisis penerapan logika fuzzy untuk memprediksi produksi minyak kelapa sawit dengan menggunakan metode Mamdani dan Sugeno diperoleh kesimpulan sebagai berikut:

1. Banyaknya minyak kelapa sawit yang harus diproduksi dengan variabel permintaan sebanyak 2.799,918 ton dan persediaan sebanyak 1.593,21 ton dengan menggunakan metode Mamdani adalah 3.085,753 ton minyak kelapa sawit yang harus diproduksi untuk memenuhi permintaan konsumen.

2. Untuk hasil prediksi produksi minyak kelapa sawit dengan menggunakan fuzzy inference system metode Mamdani dengan 9 aturan fuzzy menghasilkan nilai MAPE sebesar 17,225\%. Hal ini menunjukkan bahwa metode Mamdani baik digunakan untuk memprediksi produksi minyak kelapa sawit.

\section{DAFTAR PUSTAKA}

[1]. Avid. 2013. Diktat Fuzzy. journat.blogspot.com /2013/06/diktat-logikafuzzy.html. diakses pada 18 Maret 2013.

[2]. Setiadji. 2012. Himpunan dan Logika Samar serta Aplikasinya. Graha Ilmu. Yogyakarta.

[3]. Salikin, Fajar. 2011. Aplikasi Logika Fuzzy Dalam Optimisasi Produksi Barang Menggunakan Metode Mamdani dan Sugeno. Skripsi. Yogyakarta, FMIPA Universitas Negri Yogyakarta.

[4]. Istraniady., Priko Andrian., dan Mardiani. 2010. “Analisis Perbandingan Metode Fuzzy Tsukamoto Dan Metode Fuzzy Mamdani Pada Perbandingan Harga Sepeda Motor Bekas". Jurnal STMIK GI MDP : 2-3.

[5]. Dinas Perkebunan Prov. Kaltim. 2016 .Potensi Daerah Kabupaten Penajam Paser Utara. http://disbun.kaltimprov.go.id/statis25-potensi-daerah-kabupaten-penajam-paserutara.html. diakses pada tanggal 14 Juni 2016

[6]. BSI. 2014. Notifikasi untuk Kegiatan Penilaian Sertifikasi ISPO di PT Waru Kaltim Plantation Perkebunan dan Pabrik Kelapa Sawit di Kalimantan Timur. www.bsigroup.com/.../Public.../ISPO $\% 20$ Sta ge $\% 202 \% 20$ Publik\%20Notifikasi\%20PT. diakses pada tanggal 16 Juni 2014.

[7]. Lumbangaol, Agustina Rosario. 2011. "Sistem Penanganan Keputusan Penanganan Gizi Buruk Pada Balita Menggunakan Metode Mamdani.". Jurnal Pelita Informatika Budi Darma 4(2): 160-164.

[8]. Buffa. 1990. Manajemen Produksi. Erlangga. Jakarta.

[9]. Gaspersz, Vincent. 2005. Total Quality Management. PT. Gramedia Pustaka Utama. Jakarta.

[10]. Makridakis, S dan Wheelwright, S.C. 1999. Metode dan Aplikasi Peramalan. Erlangga. Jakarta.

[11]. Oktafri. 2001. Aplikasi Metode Simulasi Monte Carlo Untuk Menduga Debit Aliran Sungai. Thesis. Bogor, Fakultas Pertanian Lampung.

[12]. Susilo, Frans. 2003. Himpunan dan Logika Kabur Serta Aplikasinya. Graha Ilmu. Yogyakarta.

[13]. Kusumadewi, Sri. dan Purnomo Hari 2010. Artificial Intelligence: Teknik dan Aplikasinya. Graha Ilmu. Yogyakarta.

[14]. Naba, Agus. 2009. Belajar Cepat Fuzzy Logic Menggunakan Matlab. C.V Andi. Yogyakarta. 